\title{
Omenanviljelyyn kestävyyttä paikallislajikkeista
}

\author{
Tuuli Haikonen ${ }^{1}$, Marja Rantanen ${ }^{2}$, Saila Karhu ${ }^{1}$, Ibrahim Tahir ${ }^{3}$, Larisa Gustavsson ${ }^{3}$, Dag Røen ${ }^{4}$, Hilde \\ Nybom ${ }^{3}$. \\ ${ }^{1}$ Luonnonvarakeskus, Puutarhatuotanto,Toivonlinnantie 518,21500 Piikkiö.tuuli.haikonen@luke.fi \\ ${ }^{2}$ Luonnonvarakeskus, Laukaa puutarha. Antinniementie 1, 41330 Vihtavuori. \\ ${ }^{3}$ Department of Plant Breeding, SLU Balsgård, Fjälkestadsvägen 459, 29194 Kristianstad, Ruotsi. \\ ${ }^{4}$ Graminor AS, Njøsavegen 5, 6863 Leikanger, Norja.
}

\section{TIIVISTELMÄ}

Omenaa viljellään Suomessa 670 ha:n alalla. Kasvanut viljelypinta-ala mahdollistaa omenan tarjonnan myös sesongin ulkopuolella asettaen Suomessa viljeltäville lajikkeille uusia vaatimuksia. Ilmastonmuutoksen myötä vaikeasti torjuttavien tai niiden kasvitautien, joita ei voida suoraan torjua, esiintyminen on yhä yleisempää. Tulevaisuuden omenalajikkeen tulee olla taudinkestävä samalla kun mehukkuuden ja rapeuden tulee yhdistyä hyvään varastokestävyyteen. Suomalaiset paikallislajikkeet ovat usein terveitä ja niiden talvenkesto on hyvä. Paikallislajikkeiden perimä idän ja lännen risteyskohdassa tarjoaa monipuolista jalostusmateriaalia, vaikka paikallislajikkeiden alhaiset tai vaihtelevat sadot, hedelmän koko ja rakenne saattavat olla ammattiviljelyn este. Myöskään kestävyydestä uusille kasvintuhoojille ei ole tietoa.

NordApp-hankeessa yhteispohjoismaisen esijalostustutkimuksen tavoitteena on saada tietoa paikallislajikkeiden sekä pohjoisiin olosuhteisiin jalostettujen lajikkeiden ominaisuuksista ja ominaisuuksien perinnöllisestä taustasta. Varastolaikku (Neofabraea spp.) heikentää varastoitavan omenan laatua ja ilmenee usein vasta varastoinnin loppuvaiheesssa. Neofabraea-lajit aiheuttavat myös nuorten versojen näivettymistä ja versokuolio-oireita. Hankkeessa olemme kartoittaneet varastotautien esiintymistä 26 paikallislajikkeen luomuviljellyissä omenoissa ja testanneet eri lajikkeiden alttiutta varastolaikulle. Varastolaikkua esiintyi yleisesti kahtena peräkkäisenä vuotena. Eristettyjen taudinaiheuttajakantojen itiö- ja rihmastomorfologian perusteella Suomessa esiintyy ainakin kahta Neofabraea-lajia. Osassa paikallislajikkeista esiintyi vain niukasti varastolaikkua ja niiden kestävyys keinotekoiselle tartutukselle oli hyvä.

Hankkeessa on myös tutkittu Suomessa menestyvien omenalajikkeiden alttiutta hedelmäpuun syövälle (Neonectria ditissima) Ruotsissa ja etsitty DNA-markkeria taudin kenttäkestävyydelle. Taudinaiheuttaja kulkeutuu saastuneen kasvimateriaalin mukana, ja on leviämässä Etelä-Suomeen. Tautia voidaan rajoittaa vain viljelyteknisesti.

Meneillään olevissa tutkimuksissa testataan useiden paikallislajikkeiden ja pohjoisten lajikkeiden kestävyyttä varastolaikulle tartutuskokein. Tulosten perusteella haetaan omenan perimästä kestävyyteen liittyviä kandidaattialueita genominlaajuisen assosiaatioanalyysilla (GWAS). Lupaavien paikallislajikkeiden ja kaupallisten lajikkeiden välillä tehdään risteytyksiä. Risteytysjälkeläistöä karsitaan taimivaiheessa mm. varastokestävyyden, hedelmäpuun syövän ja eri varastotautien kestävyyden DNAmarkkerien avulla.

Tulosten perusteella suomalaisissa vanhoissa paikallislajikkeissa on kestävyysominaisuuksia, joita kannattaa kartoittaa tulevaisuuden omenalajikkeita varten. Saatu tieto lajikkeiden taudinkestävyydestä on hyödyllistä myös luomu- ja IPM-viljelyn lajikevalinnassa.

Asiasanat: omena, jalostus, varastointi, taudinkestävyys, perinnöllisyys 


\section{Johdanto}

Omenan viljelypinta-ala on Pohjoismaissa kasvussa ja omenan viljelyalue on laajentunut erityisesti Suomessa. Omenaa viljellään Suomessa 670 ha:n alalla. Omenan satotaso kasvaa viljelyteknisten parannusten ansiosta. Kasvanut tarjonta ja toisaalta kuluttajien kiinnostus kotimaiseen omenaan myös sesongin ulkopuolella asettaa Suomessa viljeltäville lajikkeille uusia vaatimuksia. Ilmastonmuutoksen ja kansainvälisen taimikaupan yleistymisen myötä vaikeasti torjuttavien tai niiden kasvitautien, joita ei voida suoraan torjua, esiintyminen on yhä yleisempää. Erityisesti sienitaudit hyötyvät kosteammasta ja lämpimämmästä ilmastosta. Kasvinsuojelun muuttuvat käytännöt ja kemiallisen torjunnan vähentämisen tavoitteet vaativat tulevaisuuden omenalajikkeelta taudinkestävyyttä. Kaupallisen menestymisen edellytyksenä omenan mehukkuuden ja rapeuden tulee yhdistyä hyvään varastokestävyyteen.

Yhteispohjoismainen PPP-hanke (Public-Private Partnership, Nordgen) tähtää pohjoiseurooppalaisiin olosuhteisiin sopivien lajikkeiden jalostukseen sekä jalostustoiminnan julkisen ja yksityisen sektorin yhteistyön tiivistämiseen. Omenan jalostusta ja esijalostustutkimusta edistää NordApposahanke (Prebreeding for future challenges in Nordic apples; 2012-2014, 2015-2017). NordApp-hanketta koordinoi Ruotsin Maatalousyliopisto SLU. Suomesta omenahankkeessa toimii Luonnonvarakeskus ja Norjasta kasvinjalostaja Graminor. Hankkeessa on kehitetty jalostajien yhteistyötä, mikä tukee tiedon- ja materiaalinvaihtoa ja voi mahdollistaa yhteiset jalostusohjelmat. Hankkessa tehdään yhteistutkimusta pohjoisiin olosuhteisiin sopivien lajikkeiden taudinkestävyydestä ja käyttökelpoisuudesta uusiin jalostustarpeisiin.

Pohjoismaiset omenan paikallislajikkeet ovat usein terveitä ja niiden talvenkesto on hyvä. Toisaalta paikallislajikkeiden alhaiset tai vaihtelevat sadot, hedelmän koko ja rakenne saattavat olla ammattiviljelyn este. Myöskään kestävyydestä Suomeen leviämässä oleville uusille kasvintuhoojille ei ole tietoa. Suomalaista alkuperää olevilla paikallislajikkeilla on kuitenkin jopa uniikki alkuperä itäistä ja läntistä alkuperää olevan omenamateriaalin välissä, mikä tarjoaa monipuolista jalostusmateriaalia. Kansallinen kasvigeenivaraohjelma on määritellyt omenan geenivarakokoelmaan kuuluvat lajikkeet. Näiden lajikkeiden sukulaisuussuhteita on selvitetty geneettisten markkereiden avulla, mikä auttaa suomalaisten lajikkeiden perimän vertaamista tunnettuihin viljelylajikkeisiin.

Varastolaikku (aiheuttajasieni Neofabraea spp.) heikentää varastoitavan omenan laatua. Varastotaudin oire, omenan pintasolukosta alkava ja laajeneva mätälaikku, ilmenee useilla lajikkeilla vasta varastoinnin loppuvaiheesssa. Neofabraea-lajit aiheuttavat tautia myös puissa: nuorten versojen näivettymistä ja versokuolio-oireita. Niiden tiedetään olevan myös päärynän (Pyrus communis) taudinaiheuttajia. Neofabraea-sienisuvun fylogeneettinen asema on vahvistettu mutta suku on vielä niukasti tutkittu. Neljä omenaa mädättävää lajia tunnetaan: $N$. perennans, $N$. alba ja $N$. malicorticis, sekä Neofabraea-suvun sienille läheinen anamorfinen laji, Cryptosporiopsis kienholzii. Morfologisesti osa lajeista on vaikea erottaa toisistaan. Lajikohtaisesta esiintymisestä ja suhteellisesta runsaudesta Suomessa ei ole aiempaa tietoa. Varastolaikun aiheuttajasienet aiheuttavat myös versokuolio-oireita ja pienten versojen näivettymistä omenapuussa. Epidemiologisesti verso-oireet ovat tärkeitä, sillä niissä sienitaudinaiheuttaja säilyy omenatarhassa, ja niistä sadepisaroiden ja roiskeiden avulla leviävät suvuttomat itiöt tartuttavat kehittymässä olevat omenat. Itiöt tartuttavat jopa vahingoittumatonta omenaa sillä ne säilyvät omenan korkkihuokosissa latenttina infektiona, aiheuttaen taudin vasta varastossa tai varastoinnin päätyttyä.

Hedelmäpuunsyöpä (aiheuttaja Neonectria ditissima) on vakava taimituotannon ja viljelyn ongelma Itämeren eteläpuolisissa maissa ja nykyään syöpä esiintyy yleisenä muissa Pohjoismaissa. Suomessa sitä havaitaan Ahvenanmaalla runsaasti ja mantereella paikoin. Taudinaiheuttaja kulkeutuu usein piilevänä saastuneen kasvimateriaalin mukana, ja on leviämässä Etelä-Suomeen. Taudin oireista näkyvin on puuaineksen syöpämäinen kasvu, joka kuristaa puun nestevirtausta. Hedelmätarhoissa tauti leviää itiölevintänä kaikkien vioitusten kautta, mukaanlukien lehtien ja omenoiden kantojen arvet, joten taudin määrää voidaan rajoittaa lähinnä viljelyteknisesti hoitoleikkaamalla. Talvivauriot ovat merkittävä leviämistie ja lisäävät taudin oireita, joten huonosti talvenkestävät lajikkeet kärsivät suhteellisesti enemmän kylmässä ilmastossa. 
NordApp-hankeessa yhteispohjoismaisen esijalostustutkimuksen tavoitteena on hankkia ja jakaa tietoa paikallislajikkeiden sekä pohjoisiin olosuhteisiin jalostettujen lajikkeiden ominaisuuksista ja ominaisuuksien perinnöllisestä taustasta. Erityisesti kartoitetaan perinnöllistä kestävyyttä varastoitua omenaa pilaaville varastotaudeille ja omenapuiden kasvukuntoa heikentävälle hedelmäpuunsyövälle. Näitä tauteja vastaan ei tunneta täydellistä kestävyyttä, joten hankkeessa kehitetään menetelmiä perinnöllisen kestävyyden mittaamiseen.

\section{Aineisto ja menetelmät}

\section{Varastolaikun kantojen keruu ja tartutuskokeet}

Varastolaikun ja muiden sienitautien esiintymistä varastoidussa omenassa havainnoitiin pääasiassa yhdeltä suomalaiselta luomutilalta peräisin olevien, 26 paikallislajikkeen luomuviljellyissä omenoissa vuosien 2013 ja 2014 sadoista. Näytteet (45 omenaa/lajike) jaettiin kolmeen kerranteeseen ja varastoitiin ilmavasti +3-4 ${ }^{\circ} \mathrm{C}$ lämpötilaan, yli $90 \%$ suhteellisessa kosteudessa tuuletetussa kylmävarastossa. Omenoita havainnoitiin alussa kahden viikon välein ja myöhemmin kuukausittain. Mätänemisoireiset omenat pussitettiin taudinaiheuttajan tunnistamista varten, ja itiöntuotannon lisäämiseksi pussitettuja omenoita pidettiin vuorotellen $+15-19{ }^{\circ} \mathrm{C}$ ja $+3-4{ }^{\circ} \mathrm{C}$ lämpötiloissa. Itiörakenteiden morfologia havainnoitiin stereomikroskoopilla ja itiöiden morfologia läpivalomikroskoopilla veteen tai maitohappoon tehdystä itiöpreparaatista. Tarvittaessa sienitaudinaiheuttaja eristettiin mätälaikun reunalta leikatusta palasta omenaa, joka pintasteriloitiin $70 \%$ etanolilla, huuhdeltiin steriilissä vedessä ja siirrostettiin steriilille elatusalustalle. Elatusalustoina käytettiin PDA- (potato dextrose agar) tai CMA- (corn meal agar) maljoja. Maljoilta havainnoitiin rihmaston ulkoasu sekä itiömorfologia.

Neofabraea-sienikantoja kerättiin kantakokoelmaksi, jota ylläpidettiin CMA-maljoilla. Keinotekoista tartutusta varten sienikantoja kasvatettiin CMA-maljoilla. Rihmastoa kasvatettiin huoneenlämpötilassa valossa noin kaksi viikkoa. Tuoretta sienikasvustoa otettiin kiekkoporalla (halkaisija $7 \mathrm{~mm}$ ) tartukkeeksi. Tartutettavat omenat pintasteriloitiin $70 \%$ etanolilla, huuhdeltiin steriilillä vedellä ja annettiin kuivua. Tartutus tehtiin laminaarissa: steriilillä veitsellä tehtiin kunkin omenan valo- ja varjopuolelle tasku, jonka alle tartuke painettiin. Gelatiinia $(0,1 \mathrm{~g} / \mathrm{ml})$ käytettiin haavan sulkemiseen. Negatiivisena kontrollina omenoita valetartutettiin steriilillä agarilla. Omenat varastoitiin kuten seurantakokeessa ja oireiden kehittymistä seurattiin viikoittain mittaamalla mätälaikun halkaisija.

Tartutettavien omenalajikkeiden kypsyysastetta seurattiin tartutuksen aikaan, puolivälissä koetta, sekä kokeen lopussa käyttäen Streifin indeksiä.

Tartutuskokeiden yhteisiksi lajikkeiksi on valittu 30 lajiketta ruotsalaisesta geenivarakokoelmasta. Nämä kuuluvat 1200 omenalajikkeen kokoelmaan, joista kansainvälinen FruitBreedomics-hanke on tehnyt nukleotidipolymorfismin kartoituksen (SNP-genotyping) käyttäen 480000 oligokoettimen DNAmikrosirua (Affymetrix).

\section{Hedelmäpuunsyöpä}

Eri lajikkeiden kestävyyttä versosyövälle testattiin tartutuskokein Ruotsissa ja Norjassa. Tartutusta varten koelajikkeista ja kestävistä sekä alttiista kontrollilajikkeista otettiin talvivartteet, jotka joko vartettiin perusrunkoon tai hyödettiin vesiastiassa ja testattin sellaisenaan. Vartetaimet kasvatettiin vuoden ikäisiksi. Taimet tai oksat tartutettiin sairaiden omenapuiden syöpälaikuista kerätyillä suvullisilla talvi-itiöillä: tarkka määrä itiösuspensiota $\left(10^{3}\right.$ itiötä) pipetoitiin lehtiarpea imitoivaan silmunpoistokohtaan.

Kuoliolaikkujen halkaisijaa mitattiin noin kolmen kuukauden ajan taudin kehittymisen havainnoimiseksi. Tuloksista piirrettiin keskimääräistä taudin etenemistä kuvaava käyrä lajikkeittain. Käyrän alle jäävä ala (AUDPC, area under the disease-progress curve) laskettiin lajikkeiden kestävyyden tilastollista vertailua varten ja eri tekijöiden (lajike, vuosi, kokeen toisto, koepaikka) merkittävyys testattiin varianssianalyysillä (ANOVA). 


\section{Tulokset ja tulosten tarkastelu}

Omenahankkeen vuosittaisissa kokouksissa ja työpajoissa on keskusteltu tärkeimmistä tutkittavista taudeista ja kehitetty menetelmiä taudinkestävyyden arvioimiseen. Mukaan on myös kutsuttu hankkeen ulkopuolisia tutkijoita ja jalostajia muista organisaatioista tai maista, ml. Baltian maista. Menetelmiä on onnistuneesti siirretty laboratoriosta toiseen erityisin lyhyin tutkijavierailuin. Eri jalostajien jalostusohjelmien esittelyä varten ja yhteystietojen keräämiseksi on tehty oma nettisivu. Omenanviljelijöiden tavoittamiseksi hedelmäpuunsyövästä ja varastotaudeista on kirjoitettu vuosina 2012 ja 2013 lehtiartikkeleita eri maiden ammattilehtiin. Näistä taudeista on myös pyydetty havaintoja viljelijöiltä.

Varastotautien kestävyyden testaamiseksi Ruotsissa on aiemmin tehty kokeita tartutusmenetelmän kehittämiseksi Penicillium, Colletotrichum- ja Neofabraea-sienillä. Neofabraea-sienillä menetelmää on edelleen kehitetty Suomessa ja Norjassa. Suomessa saatujen alustavien tulosten perusteella agarpalaa sisältävän rihmastotartukkeen käyttö haavatartutuksessa ei aiheuta näkyviä puolustusvasteita omenassa, ja haavakohdan suojaaminen gelatiinilla estää sekundääristen taudinaiheuttajien pääsyn haavakohtaan. Kokeissa on havaittu, että taudin mätäoireen kasvu on huomattavan tasaista.

Hedelmäpuunsyövänkestävyyden arvioimiseen on Ruotsissa ja Norjassa käyttöönotettu rinnakkain kaksi menetelmää, joilla saadaan vertailukelpoisia tuloksia: tartutukset suoraan irtoversoihin, ja tartutukset 1-vuotisaisiin vartetaimiin. Vertailevissa kokeissa on löydetty olosuhteet, joilla irtoversoihin tehdyissä kokeissa päästään vartetaimilla tehtyihin kokeisiin hyvin verrattavissa oleviin tuloksiin. Tulokset kuitenkin vaihtelevat vuosittain jonkin verran

Suomalaisessa luomuomenasta tehdyn havainnoinnin perusteella varastolaikkua esiintyi yleisesti kahden peräkkäisen vuoden (2013 ja 2014) sadoissa. Varastolaikkua havaittiin lähes kaikissa näytelajikkeissa, mutta varastolaikun määrä ja ilmenemisen ajoitus vaihteli lajikkeesta toiseen. Osassa paikallislajikkeista tautia esiintyi vain niukasti.

Itiömorfologian perusteella Suomessa esiintyy sekä Neofabraea alba -lajia että ainakin yhtä toista Neofabraea-lajia. Neofabraeaa havaittiin yli puolessa tapauksista, joissa taudinaiheuttaja tunnistettiin. Muita itiö- tai rihmastomorfologian perusteella tunnistettuja sienilajeja tai sukuja olivat Botrytis cinerea (harmaahome), jota ilmeni merkittävästi, Colletotrichum acutatum (mätälaikku) ja Fusarium spp. Viherhometta (aih. Penicillium spp) ilmeni niukasti ja vasta myöhään varastointikaudella, joten aiheuttaja oli todennäköisesti sekundäärinen mädättäjä sekainfektioissa. Penicillium omenan pilaajana on yleinen $\mathrm{mm}$. Etelä-Ruotsissa, mutta Suomen ilmastossa sen merkitys on todennäköisesti pienempi. Omenoide käsittelyllä on myös vaikutusta, sillä Penicillium tarvitsee ulkoisia vaurioita taudin aiheuttamiseen.

Kantakokoelman eri Neofabraea-kantojen taudinaiheuttamiskykyä testattiin tartutuskokein, ja todettiin sienten patogeenisuuden omenalle säilyneen maljakasvatuksessa. Vuoden 2015 tartutuskokeita varten valittiin neljä patogeenista Neofabraea-kantaa, joista kaksi edusti $N$. alba-lajia.

Meneillään olevissa tutkimuksissa verrataan useiden paikallislajikkeiden ja pohjoisten lajikkeiden kestävyyttä varastolaikulle tartutuskokein Suomessa ja Ruotsissa. Kokeet toistetaan vuonna 2016. Tavoitteena on verrata yhteensä noin 45 lajikkeen kestävyyttä varastolaikulle, näistä lajikkeista noin 30 on olemassa SNP-tiedot. Alustavien tulosten perusteella lajikkeiden välillä on eroja taudin etenemisnopeudessa. Lisäksi eri sienikantojen tai -lajien välillä on eroa niiden virulenssissa omenalla. Tulosten perusteella haetaan omenan perimästä kestävyyteen liittyviä kandidaattialueita genominlaajuisen assosiaatioanalyysin (GWAS) keinoin.

Noin 30 Pohjoismaissa yleisen omenalajikkeen hedelmäpuunsyövänkestävyyttä on testattu tartutuskokein Norjassa ja Ruotsissa. Kahden vuoden tulosten perusteella Suomen tai Ahvenanmaan ilmastossa menestyvistä lajikkeista osa oli hyvin alttiita (Åkerö, Rubinola, Nanna, Heta, Konsta, Vuokko), osa kohtalaisen kestäviä (Aroma, Discovery, Santana, Valtti, Punakaneli). 


\section{Johtopäätökset}

Pohjoismainen yhteistyö geneettisten resurssien karakterisoinnissa ja kokeiden hajauttaminen eri maihin mahdollistaa laajemmat kokeet ja vaikeasti testattavien taudinkestävyysominaisuuksien kartoittamisen. Ilmiasutiedon kertyminen useasta lajikkeesta mahdollistaa genominlaajuisen nukleotidipolymorfismiin perustuvat genomisen assosiaatiotutkimuksen hyödyntämisen. Assosiaatiotutkimuksen tuloksilla voidaan nopeuttaa monivuotisten kasvien jalostusta ottamalla käyttöön uusia geneettisiä markkereita jalostusmateriaalin varhaisen vaiheen valintaan. Lähitulevaisuudessa lupaavien paikallislajikkeiden ja kaupallisten lajikkeiden välillä tehdään risteytyksiä. Risteytysjälkeläistöjä tullaan taimivaiheessa karsimaan kehitteillä olevien DNA-markkerien avulla mm. varastokestävyyden, hedelmäpuun syövän ja eri varastotautien kestävyyden suhteen.

Pyrkimys vähäiseen torjunta-aineiden käyttöön ja huoltovarmuuteen edellyttää, että uusien kasvintuhoojien leviämiseen varaudutaan aikaisessa vaiheessa ennen taudin yleistymistä tai niiden merkityksen kasvua. Hedelmäpuunsyövän yleistyminen vaikuttaa lajikevalintaan muissa Pohjoismaissa, ja tulee Suomessakin rajoittamaan lajikevalikoimaa taimistoilla ja omenatarhoilla. Saatu tieto lajikkeiden hedelmäpuunsyövänkestävyydestä on erityisen hyödyllistä myös luomu- ja IPM-viljelyn lajikevalinnassa. Edelleenkään useimmista Suomen oloihin riittävän talvenkestävistä lajikkeista ei tunneta niiden kestävyyttä, mutta tiedetään että joukossa on useita alttiita lajikkeita.

Alustavat tulokset varastolaikun ilmenemisestä lupaavat, että suomalaisissa vanhoissa paikallislajikkeissa on kestävyysominaisuuksia varastolaikkua vastaan. Kaikkien eri varastolaikun aiheuttajien lajilleen tunnistamiseksi tarvittaisiin vielä DNA-perusteinen lajimääritys.

Tutkitut hedelmäpuunsyövän ja varastolaikun aiheuttajasienet aiheuttavat tautia sekä puuaineksessa että hedelmässä. Varastolaikku samoin kuin hedelmäpuunsyövän hedelmissä aiheuttama mätäoire kuuluvat korkkihuokosissa piileviin tauteihin. Vastaavat korkkihuokosten kautta tarttuvat sieni- tai bakteeritaudinaiheuttajat vaivaavat hedelmien lisäksi myös esimerkiksi perunaa ja juureksia varastossa, joten niitä vastaan toimivassa kasvin puolustuksessa voi olla yhteisiä piirteitä.

Tulokset auttavat varautumaan ilmastonmuutoksen tuomaan uuteen uhkaan omenanviljelyn elinkeinolle, lisäävät tietoa omenan paikallislajikkeiden käyttömahdollisuuksista sekä auttavat ymmärtämään kasvien puolustautumista taudinaiheuttajia vastaan.

\section{Kirjallisuus}

Antanaviciute, L., Fernández-Fernández, F., Jansen, J., Banchi, E., Evans, K. M., Viola, R., Velasco, R., Dunwell, J. M., Troggio, M. \& Sargent, D. J. 2012. Development of a dense SNP-based linkage map of an apple rootstock progeny using the Malus Infinium whole genome genotyping array. BMC Genomics 13: 203.

Abeln, E. C. A., Pagter, M. A. de \& Verkley, G. J. M. 2000. Phylogeny of Pezicula, Dermea and Neofabraea inferred from partial sequences of the nuclear ribosomal RNA gene cluster. Mycologia 92: 685-693.

Chen, C., Verkley, G. J. M., Sun, G., Groenewald, J. Z. \& Crous, P. W. 2015. Redefining common endophytes and plant pathogens in Neofabraea, Pezicula, and related genera. Fungal Biology, http://dx.doi.org/10.1016/j.funbio.2015.09.013.

Beresford, R. M. \& Kim, K. S. 2010. Identification of regional climatic conditions favorable for development of European canker of apple. Phytopathology 101: 135-146.

Borve, J., Talgo, V. \& Stensvand, A. 2015. Apple canker caused by Neonectria ditissima in Norway. IOBCWPRS Bulletin 110: 105-106.

Edney, K. L. 1956. The rotting of apples by Gloeosporium perennans Zeller \& Childs. Annals of Applied Biology 44: 113-128.

Garkava-Gustavsson, L., Mujaju, C., Sehic, J., Zborowska, A., Backes, G. M., Hietaranta T. \& Antonius, K. 2013. Genetic diversity in Swedish and Finnish heirloom apple cultivars revealed with SSR markers. Scientia Horticulturae 162: 43-48. 
Garkava-Gustavsson, L., Zborowska, A., Sehic, J., Rur, M., Nybom, H., Englund, J.-.E., Lateur, M., Van de Weg, E. and Holefors, A. 2013. Screening of apple cultivars for resistance to European canker, Neonectria ditissima. Acta Hortic. 976: 529-536.

Ghasemkhani, M., Liljeroth, E., Sehic, J., Zborowska, A. \& Nybom, H. 2015. Cut-off shoots method for estimation of partial resistance in apple cultivars to fruit tree canker caused by Neonectria ditissima. Acta Agriculturae Scandinavica, Section B - Soil \& Plant Science 65: 412-421.

Heinonen, M., Kinnanen, H., Valo, R., Antonius, K. \& Ala-Kaarre, J. 2014. Nurkkapuut kansan sydämessä. Kirjassa: Kiviharju, Elina (toim.). Viljelykasvien geenivarat talteen ja käyttöön - Suomen kansallisen kasvigeenivaraohjelman $\quad 10$-vuotisseminaarin $\quad$ (29.8.2013) $\quad$ satoa. $\quad$ MTT $\quad$ Raportti $139, \quad 40-43 \quad$ s. https://portal.mtt.fi/portal/page/portal/www/Tietopaketit/Kasvigeenivarat/mttraportti139.pdf

Henriquez, J. L., Sugar, D. \& Spotts R. A. 2006. Induction of cankers on pear tree branches by Neofabraea alba and $N$. perennans, and fungicide effects on conidial production on cankers. Plant Disease 90: 481-486.

Spotts, R. A., Seifert, K. A., Wallis, K. M., Sugar, D., Xiao, C. L., Serdani, M. \& Henriquez, J. L. 2009. Description of Cryptosporiopsis kienholzii and species profiles of Neofabraea in major pome fruit growing districts in the Pacific Northwest USA. Mycological Research 113: 1301-1311.

Weber, R. W. S. 2014. Biology and control of the apple canker fungus Neonectria ditissima (syn. N. galligena) from a Northwestern European perspective. Erwerbs-Obstbau 56: 95-107.

Weg, W. E. Van De. 1987. Note on an inoculation method to infect young apple seedlings with Nectria galligena Bres. Euphytica 36: 853-854. 